\title{
EFFECT OF SELENIUM ON SALT TOLERANCE IN MAIZE PLANTS
}

\author{
Maha A. I. Dekhil(1); Mohamed F. M. Ibrahim(2) \\ Hani S. Saudy ${ }^{(2)}$ and Sanaa A. M. Zaghlool ${ }^{(2)}$
}

1) Central Administration for Seed Testing \& Certification 2) Faculty of Agriculture, Ain Shams University

\begin{abstract}
Two pot experiments during the seasons of 2017 and 2018 were conducted to investigate the effect of Se as $\mathrm{Na}_{2} \mathrm{SeO}_{4}(2.5$ and $5 \mu \mathrm{M})$ as foliar applications on growth, photosynthetic pigments, $\mathrm{Na} / \mathrm{K}$ homeostasis and eventually the yield of maize plants grown under three different levels of salinity $(0,50$ and $100 \mathrm{mM} \mathrm{NaCl})$. The results indicated that Se at $2.5 \mu \mathrm{M}$ recorded the highest significant values in leaves and stem dry weights, total grain yield plant ${ }^{-1}$ and grain filling as indicated by the weight of 100 kernels; As well as, Chl a, Chl b and $\mathrm{K}$ concentrations. On contrary, there was a significant decrease in $\mathrm{Na}$ concentration and $\mathrm{Na} / \mathrm{K}$ ratio. Additionally, carotenoids did not reveal any significant changes between Se-treated plants and the untreated ones.
\end{abstract}

Key words: Zea mays, selenium, salinity, pigments, ionic balance and yield.

\section{INTRODUCTION}

Salinity is considered one of the most environmental factors that drastically restrict plant growth and productivity (Dash and Panda, 2001; Schleiff, 2008). It can accelerate senescence, leaf abscission and plant death (Allu et al., 2014; Sade et al., 2017). Additionally, salt stress can negatively affect photosynthesis (Munns and Tester, 2008; Hniličková et al., 2017), water absorption (Munns, 2002), nutrient balance (Munns, 2005) and hormone metabolism (Fahad et al., 2015). It can also disturb the stability of 
Journal of Environmental Sciences (JES)

Institute of Environmental Studies and Research, Ain Shams University

Dekhil, Maha et al.

cell membranes, activity of enzymatic systems, and production of reactive oxygen species (ROS) (Pang and Wang, 2008; Jamil et al., 2012).

Maize (Zea mays) represents the third most important cereal crops cultivated worldwide after wheat and rice. It has a high nutritional value for both human and animal and provides suitable raw materials for several industries such as starch, fodder, silage and biofuels (Dhugga, 2007; Ostrander, 2015; Kleinmans et al., 2016). Under saline conditions; maize plants could demonstrate sever damages and significant losses in their growth and yield (Farooq et al., 2015).

Selenium (Se) is an essential trace element with dual effects on the higher plants; At low concentrations, it stimulates plant growth (Turakainen et al., 2004), photosynthesis (Habibi, 2017), antioxidant capacity (Jiang et al., 2017), delay senescence (Xue et al., 2001) and induce tolerance to various abiotic stresses including drought (Germ et al., 2007; Ibrahim and Ibrahim, 2016), salinity (Hawrylak-Nowak, 2009; Jiang et al., 2017; Elkelish et al., 2019), heavy metals (Cartes et al., 2010), UV-irradiation (Valkama et al., 2003), cold (Chu et al., 2010), high temperatures (Djanaguiraman et al., 2010) and oxidative stress (Hasanuzzaman et al., 2010). Adversely, at high concentrations, Se could be toxic because it may be similar and replaced with Sulphur in amino acids and consequently corrupt the three-dimensional structure of proteins and enzymatic functions (Amweg et al., 2003). 
Currently, with global climatic changes and scarcity of freshwater particularly in the arid and semi-arid regions like Egypt, increasing the risk of soil salinization has become one of the most challenges that could threaten the existence of mankind by affecting sustainable agriculture and different socio-economic activities. Therefore, this study aimed to know the possible role of foliar application of $\mathrm{Se}$ as $\mathrm{Na}_{2} \mathrm{SeO}_{4}(0,2.5$ and $5 \mu \mathrm{M})$ on regulating maize salt tolerance by affecting its growth, yield and several biochemical constituents.

\section{MATERIALS AND METHODS}

Experiment Layout and growth conditions: Two pot experiments were conducted on $25^{\text {th }}$ and $22^{\text {th }}$ of May 2017 and 2018 respectively in the Experimental Farm, Faculty of Agriculture, Ain shams University, Cairo, Egypt to investigate the effect of foliar applications with distilled water as a control and selenium (Se) as $\mathrm{Na}_{2} \mathrm{SeO}_{4}(2.5$ and $5 \mu \mathrm{M})$ on maize plants irrigated with three different concentrations of saline water $(0,50$ and 100 $\mathrm{mM} \mathrm{NaCl}$ ). The foliar application of $\mathrm{Na}_{2} \mathrm{SeO}_{4}$ was done twice at 30 and 60 days after sowing; whereas, the irrigation with saline water was started at 36 days after sowing (vegetative growth stage). The experimental design was split plot with Completely Randomized Block Design (CRBD) of main plots. All pots (324) were divided to three equal main groups as replicates. Different saline irrigation treatments were distributed randomly into each replicate as main plots and the foliar treatments as sub-plots. All different treatments of 
Journal of Environmental Sciences (JES)

Institute of Environmental Studies and Research, Ain Shams University

Dekhil, Maha et al.

irrigation and foliar applications to each experiment were respectively arranged as follow: 
(1)Tap water + distilled water

(2) Tap water $+\mathrm{Na}_{2} \mathrm{SeO}_{4}$ at $2.5 \mu \mathrm{M}$

(3) Tap water $+\mathrm{Na}_{2} \mathrm{SeO}_{4}$ at $5 \mu \mathrm{M}$

(4)Saline water $(50 \mathrm{mM} \mathrm{NaCl})+$ distilled water

(5)Saline water $(50 \mathrm{mM} \mathrm{NaCl})+\mathrm{Na}_{2} \mathrm{SeO}_{4}$ at $2.5 \mu \mathrm{M}$

(6)Saline water $(50 \mathrm{mM} \mathrm{NaCl})+\mathrm{Na}_{2} \mathrm{SeO}_{4}$ at $5 \mu \mathrm{M}$

(7)Saline water $(100 \mathrm{mM} \mathrm{NaCl})+$ distilled water

(8)Saline water $(100 \mathrm{mM} \mathrm{NaCl})+\mathrm{Na}_{2} \mathrm{SeO}_{4}$ at $2.5 \mu \mathrm{M}$

(9)Saline water $(100 \mathrm{mM} \mathrm{NaCl})+\mathrm{Na}_{2} \mathrm{SeO}_{4}$ at $5 \mu \mathrm{M}$

Seeds of maize hybrid triple white (Giza 310) were purchased from The Agriculture Research Center, Giza, Egypt. Five seeds were sown in plastic pots $50 \mathrm{~cm}$ length $X 30 \mathrm{~cm}$ width filled with $27 \mathrm{~kg}$ pre-washed sand. After three weeks; pots were thinned to one uniform seedling in size to each pot in order to homogenize the plant material used in the experiments. Applied fertilizers were calculated per pot as recommended by Egyptian Ministry of Agriculture in sandy soil. In the first dose, each pot was provided with $1.6 \mathrm{~g}$ calcium triple superphosphate $\left(37.5 \% \mathrm{P}_{2} \mathrm{O}_{5}\right), 2.1 \mathrm{~g}$ ammonium nitrate $(33.5 \%$ $\mathrm{N})$ and $1.9 \mathrm{~g}$ potassium sulfate $(48 \% \mathrm{~K})$ at two weeks after sowing. In the second and third doses, equal amounts of $\mathrm{N}$ and $\mathrm{K}$ fertilizers were provided with two weeks intervals at 30 and 45 days after sowing. The other macro and micronutrients, disease and pest control programs were also followed according to the recommendations of Egyptian Ministry of Agriculture. 
Journal of Environmental Sciences (JES)

Institute of Environmental Studies and Research, Ain Shams University

Dekhil, Maha et al.

\section{Studied parameters}

\section{Vegetative growth}

The leaves, stem and total shoot dry weight of maize plants were determined at 90 days after sowing, the samples were cleaned by washing with tap water then dried in an air-forced ventilated oven at $70{ }^{\circ} \mathrm{C}$ until a constant weight.

\section{Biochemical constituents}

\section{Leaf pigments}

Chlorophyll a, b and carotenoids were extracted in pure acetone and determined as described by Costache et al. (2012). The concentrations were calculated using the following equations:

Chlorophyll $\mathrm{a}=11.75$ A662 - 2.350 A645

Chlorophyll b=18.61 A645 - 3.960 A662

Carotenoids $=1000 \mathrm{~A} 470-2.270 \mathrm{Chl} \mathrm{a}-81.4 \mathrm{Chl} \mathrm{b} / 227$.

Leaf Mineral Concentration: Dry leaves were grounded and digested using sulphuric acid and hydrogen peroxide. Leaf mineral concentrations of $\mathrm{Na}$ and $\mathrm{K}$ were determined according to Cottenie et al. (1982).

Yield and its components: Ears of maize plants were harvested at 115 days after sowing; the total amount of grains (g. plant ${ }^{-1}$ ) and 100 kernel weights were estimated.

Statistics: Data were analyzed using SAS (1988). Means were calculated and Duncan's multiple range test $(\mathrm{P} \leq 0.05)$ was used to determine the significant differences between means. 
Journal of Environmental Sciences (JES)

Institute of Environmental Studies and Research, Ain Shams University

Dekhil, Maha et al.

\section{RESULTS AND DISCUSSION}

Vegetative growth: Data presented in Table 1 show that increasing the level of salinity negatively affected $(P \leq 0.05)$ leaves, stem and total shoot dry weights of maize plants. In this regard, the lowest significant $(P \leq 0.05)$ values were observed at high salinity level $(100 \mathrm{mM})$ compared to the moderate one $(50 \mathrm{mM})$ and those that had grown in the absence of applied $\mathrm{NaCl}$. Maize has been known as the most susceptible crop of cereals to salt stress (Katerji et al., 1996) In several previous studies, it was established that all growth parameters including plant length, shoot fresh and dry weights, leaf and internode growth rate of maize plants had been reduced by exposing to a wide array of $\mathrm{NaCl}$ salt concentrations (Cramer et al., 1994; Parvaiz, 2014; Soufan and Okla, 2014; Farooq et al., 2015); These effects could be directly attributed to decrease the rate of cell division and elongation (Barakat, 2003; Tabur and Demir, 2010; Valenzuela et al., 2016) through affecting the activities of some transport proteins like $\mathrm{H}^{+}$-PPase and $\mathrm{H}^{+}$-ATPase (Shi et al., 2007) or indirectly by affecting multiple vital processes including protein, DNA and RNA synthesis, enzyme function, photosynthesis and respiration (Seckin et al., 2009; Sabbagh et al., 2014; Farooq et al., 2015). 
Table (1): Effect of foliar application of $\mathrm{Na}_{2} \mathrm{SeO}_{4}$ at 0 (distilled water) as a control, 2.5 and $5 \mu \mathrm{M}$ on some growth parameters of maize plant irrigated with three different concentrations of saline water as $\mathrm{NaCl}$ at 90 days after sowing.

\begin{tabular}{|c|c|c|c|c|c|c|c|c|}
\hline \multirow{3}{*}{$\begin{array}{c}\mathrm{Na}_{2} \mathrm{Se} \\
\mathrm{O}_{4} \\
(\mu \mathrm{M})\end{array}$} & \multicolumn{3}{|c|}{ Salinity levels as NaCl } & \multirow{3}{*}{ Mean } & \multicolumn{3}{|c|}{ Salinity levels as $\mathrm{NaCl}$} & \multirow{3}{*}{ Mean } \\
\hline & $\begin{array}{c}0 \\
\mathrm{mM}\end{array}$ & $50 \mathrm{mM}$ & $\begin{array}{l}100 \\
\mathrm{mM}\end{array}$ & & $0 \mathrm{mM}$ & $\begin{array}{c}50 \\
\mathrm{mM}\end{array}$ & $\begin{array}{l}100 \\
\mathrm{mM}\end{array}$ & \\
\hline & \multicolumn{3}{|c|}{2017} & & \multicolumn{3}{|c|}{2018} & \\
\hline \multicolumn{9}{|c|}{ Leaves dry weight (g. plant $^{-1}$ ) } \\
\hline 0 & $\begin{array}{c}58.76 \\
a b\end{array}$ & $\begin{array}{c}48.11 \\
\text { cde }\end{array}$ & $39.06 \mathrm{f}$ & $48.64 \mathrm{~B}$ & $\begin{array}{c}66.91 \\
\text { ab }\end{array}$ & $\begin{array}{c}58.75 \\
\text { cd }\end{array}$ & $48.72 \mathrm{f}$ & $\begin{array}{c}58.13 \\
\text { B }\end{array}$ \\
\hline 2.5 & $\begin{array}{c}63.05 \\
a\end{array}$ & $\begin{array}{c}54.75 \\
\text { bc }\end{array}$ & $\begin{array}{c}44.00 \\
\text { def }\end{array}$ & $\begin{array}{c}53.94 \\
\text { A }\end{array}$ & $\begin{array}{c}71.65 \\
\mathrm{a}\end{array}$ & $\begin{array}{c}62.61 \\
\text { bc }\end{array}$ & $\begin{array}{c}54.70 \\
\mathrm{de}\end{array}$ & $\begin{array}{c}62.99 \\
\text { A }\end{array}$ \\
\hline 5 & $\begin{array}{c}61.92 \\
\mathrm{a}\end{array}$ & $\begin{array}{c}50.05 \\
\mathrm{~cd}\end{array}$ & 42.66 ef & $\begin{array}{c}51.55 \\
\mathrm{AB}\end{array}$ & $\begin{array}{c}69.93 \\
\mathrm{a}\end{array}$ & $60.06 \mathrm{c}$ & $\begin{array}{c}51.74 \\
\text { ef }\end{array}$ & $\begin{array}{c}60.57 \\
\mathrm{AB}\end{array}$ \\
\hline Mean & $\begin{array}{c}61.25 \\
\mathrm{~A}\end{array}$ & $\begin{array}{c}50.97 \\
\text { B }\end{array}$ & $41.91 \mathrm{C}$ & & $\begin{array}{c}69.50 \\
\mathrm{~A}\end{array}$ & $60.47 \mathrm{~B}$ & $\begin{array}{c}51.72 \\
\mathrm{C}\end{array}$ & \\
\hline \multicolumn{9}{|c|}{ Stem dry weight (g. plant $^{-1}$ ) } \\
\hline 0 & $\begin{array}{c}203.97 \\
\text { ab }\end{array}$ & $\begin{array}{c}169.10 \\
\mathrm{c}\end{array}$ & $\begin{array}{c}160.62 \\
c\end{array}$ & $\begin{array}{c}177.9 \\
0 \mathrm{~B}\end{array}$ & $\begin{array}{c}247.87 \\
\text { b }\end{array}$ & $\begin{array}{c}190.72 \\
\text { cd }\end{array}$ & $\begin{array}{c}158.31 \\
\mathrm{e}\end{array}$ & $\begin{array}{c}198.97 \\
\text { B }\end{array}$ \\
\hline 2.5 & $\begin{array}{c}229.68 \\
a\end{array}$ & $\begin{array}{c}186.86 \\
\text { bc }\end{array}$ & $\begin{array}{c}176.59 \\
\text { bc }\end{array}$ & $\begin{array}{c}197.7 \\
1 \mathrm{~A}\end{array}$ & $\begin{array}{c}276.22 \\
a\end{array}$ & $\begin{array}{c}211.95 \\
\mathrm{c}\end{array}$ & $\begin{array}{c}171.95 \\
\mathrm{de}\end{array}$ & $\begin{array}{c}220.04 \\
\text { A }\end{array}$ \\
\hline 5 & $\begin{array}{c}224.86 \\
\mathrm{a}\end{array}$ & $\begin{array}{c}187.27 \\
b c\end{array}$ & $\begin{array}{c}170.09 \\
\mathrm{c}\end{array}$ & $\begin{array}{l}194.0 \\
7 \mathrm{AB}\end{array}$ & $\begin{array}{c}256.61 \\
a b\end{array}$ & $\begin{array}{c}208.38 \\
\text { c }\end{array}$ & $\begin{array}{c}167.01 \\
\mathrm{e}\end{array}$ & $\begin{array}{c}210.66 \\
\mathrm{AB}\end{array}$ \\
\hline Mean & $\begin{array}{c}219.50 \\
\text { A }\end{array}$ & $\begin{array}{c}181.07 \\
\text { B }\end{array}$ & $\begin{array}{c}169.10 \\
\text { B }\end{array}$ & & $\begin{array}{c}260.23 \\
\text { A }\end{array}$ & $\begin{array}{c}203.68 \\
\text { B }\end{array}$ & $\begin{array}{c}165.75 \\
\mathrm{C}\end{array}$ & \\
\hline
\end{tabular}


Cont. Table (1):

\begin{tabular}{|c|c|c|c|c|c|c|c|c|}
\hline \multicolumn{10}{|c|}{ Total shoot dry weight (g. plant ${ }^{-1}$ ) } \\
\hline 0 & $\begin{array}{c}262.73 \\
\mathrm{bc}\end{array}$ & $\begin{array}{c}217.20 \\
\mathrm{de}\end{array}$ & $\begin{array}{c}199.68 \\
\mathrm{e}\end{array}$ & $\begin{array}{c}226.5 \\
4 \mathrm{~B}\end{array}$ & $\begin{array}{c}314.78 \\
\mathrm{~b}\end{array}$ & $\begin{array}{c}249.48 \\
\mathrm{~d}\end{array}$ & $\begin{array}{c}207.03 \\
\mathrm{e}\end{array}$ & $\begin{array}{c}257.10 \\
\mathrm{~B}\end{array}$ \\
\hline \multirow{2}{*}{2.5} & $\begin{array}{c}292.73 \\
\mathrm{a}\end{array}$ & $\begin{array}{c}241.61 \\
\mathrm{~cd}\end{array}$ & $\begin{array}{c}220.59 \\
\mathrm{de}\end{array}$ & $\begin{array}{c}251.6 \\
4 \mathrm{~A}\end{array}$ & $\begin{array}{c}347.87 \\
\mathrm{a}\end{array}$ & $\begin{array}{c}274.56 \\
\mathrm{c}\end{array}$ & $\begin{array}{c}226.65 \\
\mathrm{e}\end{array}$ & $\begin{array}{c}283.03 \\
\mathrm{~A}\end{array}$ \\
\hline 5 & $\begin{array}{c}286.78 \\
\mathrm{ab}\end{array}$ & $\begin{array}{c}237.32 \\
\mathrm{~cd}\end{array}$ & $\begin{array}{c}212.75 \\
\mathrm{de}\end{array}$ & $\begin{array}{c}245.6 \\
2 \mathrm{~A}\end{array}$ & $\begin{array}{c}326.53 \\
\mathrm{ab}\end{array}$ & $\begin{array}{c}268.43 \\
\mathrm{~cd}\end{array}$ & $\begin{array}{c}218.75 \\
\mathrm{e}\end{array}$ & $\begin{array}{c}271.24 \\
\mathrm{~A}\end{array}$ \\
\hline \multirow{2}{*}{ Mean } & $\begin{array}{c}280.75 \\
\mathrm{~A}\end{array}$ & $\begin{array}{c}232.04 \\
\mathrm{~B}\end{array}$ & $\begin{array}{c}211.01 \\
\mathrm{C}\end{array}$ & & $\begin{array}{c}329.73 \\
\mathrm{~A}\end{array}$ & $\begin{array}{c}264.16 \\
\mathrm{~B}\end{array}$ & $\begin{array}{c}217.48 \\
\mathrm{C}\end{array}$ & \\
\hline
\end{tabular}

In each variable, data followed by the same letters (small letters for interactions and capital letters for means) are not significantly different using Duncan multiple range test at $5 \%$ level.

Respecting the effect of foliar applications of Se, it can be observed that all investigated growth parameters (leaves, stem and total soot dry weights) was enhanced by both examined foliar treatments of Se at 2.5 or $5 \mu \mathrm{M}$ compared to the control in the two seasons. In this respect, the highest significant $(P \leq 0.05)$ increases in shoot dry weight were obtained by the lower concentration of $\mathrm{Se}$ at $2.5 \mu \mathrm{M}$ compared to the other treatments in both seasons. Under salt stress, exogenous applied-Se was showed to stimulate growth of many plant species such as canola (Hashem et al., 2013), tomato (Diao et al., 2014) lettuce (Khalifa et al., 2016), maize (Jiang et al., 2017) and wheat (Elkelish et al., 2019). This positive effect could be due to that appliedSe could be implicated in photosynthesis and regulating of water status and ionic balance of salt-affected plants; Furthermore, it can act as an antioxidant by increasing the activities of both enzymatic and non-enzymatic antioxidant 
Journal of Environmental Sciences (JES)

Institute of Environmental Studies and Research, Ain Shams University

Dekhil, Maha et al.

systems leading to reducing $\mathrm{NaCl}$-induced oxidative damages (Jiang et al., 2017; Elkelish et al., 2019).

Regarding the effect of interaction between the different levels of salinity and Se-applications, it can be noticed that the treatment of Se at $2.5 \mu \mathrm{M}$ under non-saline conditions gave the highest significant $(P \leq 0.05)$ results in all studied growth parameters compared to the untreated control in both seasons; whereas, under saline conditions, with exception of leaves dry weight in the second season, the general tendency was that no significant differences were detected between both Se foliar applications and the untreated plants in both seasons.

Photosynthetic pigments: Data in Table 2 show that under saline conditions, photosynthetic pigments including chlorophylls ( $\mathrm{Chl}$ a and $\mathrm{Chl} b$ ) and carotenoids were significantly $(P \leq 0.05)$ decreased by raising the level of salinity. These effects could be attributed to that salt stress dramatically alters the chloroplast ultrastructure (Zhang et al., 2010) and consequently its pigment complex composition (Parida et al., 2003), it causes a considerable elevating in the concentration of reactive oxygen species (ROS) (MenezesBenavente et al., 2004; Elkelish et al., 2019) leading to fast degradation to the leaf pigments.

Concerning the effect of Se treatments, it can be observed that both examined concentrations of Se exhibited an improving in the concentrations of chlorophylls (Chl a and $\mathrm{Chl}$ b). In this regard, it was found that the treatment of Se at $2.5 \mu \mathrm{M}$ revealed the highest significant $(P \leq 0.05)$ increases 
in both traits compared to the untreated control in both seasons. On the other hand, no significant differences were observed between all foliar treatments in respect to the concentration of carotenoids.

Improving the concentration of chlorophylls in the Se-treated plants in comparison to the untreated ones had been reported in many previous studies (Moldovan et al., 2009; Saffaryazdi et al., 2012; Ibrahim and Ibrahim, 2016; Elkelish et al., 2019). Selenium at optimal concentration may be involved in enhancing leaf pigments by increasing the capacity of antioxidants and delaying the leaf senescence (Germ et al., 2007; Elkelish et al., 2019). In this context it was found that applied Se increased the activities of several antioxidant enzymes and inhibited the excessive release of ROS (Hartikainen et al., 2000; Ibrahim and Ibrahim, 2016). Conversely, under the circumstances of this study, the non-significant changes in carotenoids between all Se-treated plants and those that untreated indicate that in maize plants, Se may be related to another antioxidant systems or it has not been involved in the pathway of the biosynthesis of carotenoids.

Concerning the effect of interaction, it is obvious that the treatment of Se at $2.5 \mu \mathrm{M}$ achieved the highest values $(P \leq 0.05)$ of $\mathrm{Chl}$ a under all levels of salinity in both seasons respectively. On the other hand, all foliar treatments did not affect the concentration of $\mathrm{Chl} b$ and carotenoids under the same level of salinity in both seasons. 
Table (2): Effect of foliar application of $\mathrm{Na}_{2} \mathrm{SeO}_{4}$ at 0 (distilled water) as a control, 2.5 and $5 \mu \mathrm{M}$ on photosynthetic pigments of maize plant irrigated with three different concentrations of saline water as $\mathrm{NaCl}$ at 90 days after sowing.

\begin{tabular}{|c|c|c|c|c|c|c|c|c|}
\hline \multirow{3}{*}{$\begin{array}{c}\text { Na2So } \\
4 \\
(\mu \mathrm{M})\end{array}$} & \multicolumn{3}{|c|}{ Salinity levels as $\mathrm{NaCl}$} & \multirow{3}{*}{ Mean } & \multicolumn{3}{|c|}{ Salinity levels as $\mathrm{NaCl}$} & \multirow{3}{*}{ Mean } \\
\hline & $0 \mathrm{mM}$ & $\begin{array}{c}50 \\
\mathrm{mM}\end{array}$ & $\begin{array}{l}100 \\
\mathrm{mM}\end{array}$ & & $0 \mathrm{mM}$ & $50 \mathrm{mM}$ & $\begin{array}{l}100 \\
\mathrm{mM}\end{array}$ & \\
\hline & \multicolumn{3}{|c|}{2017} & & \multicolumn{3}{|c|}{2018} & \\
\hline \multicolumn{9}{|c|}{ Chl a (mg/g f.wt) } \\
\hline 0 & $2.49 \mathrm{~b}$ & $2.19 \mathrm{~d}$ & $1.90 \mathrm{f}$ & $2.19 \mathrm{C}$ & $\begin{array}{c}2.54 \\
a b\end{array}$ & $2.22 \mathrm{c}$ & $1.98 \mathrm{~d}$ & $2.25 \mathrm{~B}$ \\
\hline 2.5 & $2.60 \mathrm{a}$ & $2.30 \mathrm{c}$ & $2.02 \mathrm{e}$ & $2.31 \mathrm{~A}$ & $2.65 \mathrm{a}$ & $2.44 \mathrm{~b}$ & $2.07 \mathrm{~cd}$ & $2.39 \mathrm{~A}$ \\
\hline 5 & $\begin{array}{c}2.52 \\
\mathrm{ab}\end{array}$ & $\begin{array}{c}2.25 \\
\mathrm{~cd}\end{array}$ & $1.99 \mathrm{e}$ & $2.25 \mathrm{~B}$ & $\begin{array}{c}2.60 \\
\mathrm{ab}\end{array}$ & $2.40 \mathrm{~b}$ & $2.02 \mathrm{~d}$ & $\begin{array}{c}2.34 \\
\mathrm{AB}\end{array}$ \\
\hline Mean & $\begin{array}{c}2.53 \\
\mathrm{~A}\end{array}$ & $\begin{array}{c}2.25 \\
\mathrm{~B} \\
\end{array}$ & $1.97 \mathrm{C}$ & & $\begin{array}{c}2.60 \\
\mathrm{~A} \\
\end{array}$ & $2.35 \mathrm{~B}$ & $2.03 \mathrm{C}$ & \\
\hline \multicolumn{9}{|c|}{ Chl b (mg/g f.wt) } \\
\hline 0 & $1.40 \mathrm{a}$ & $\begin{array}{c}1.22 \\
b c\end{array}$ & $1.19 \mathrm{c}$ & $1.27 \mathrm{~B}$ & $1.48 \mathrm{a}$ & $\begin{array}{l}1.25 \\
\text { bcd }\end{array}$ & $1.15 \mathrm{e}$ & $1.29 \mathrm{~B}$ \\
\hline 2.5 & $1.47 \mathrm{a}$ & $1.29 \mathrm{~b}$ & $1.25 \mathrm{bc}$ & $1.34 \mathrm{~A}$ & $1.55 \mathrm{a}$ & $1.32 \mathrm{~b}$ & $\begin{array}{l}1.21 \\
\text { cde }\end{array}$ & $1.36 \mathrm{~A}$ \\
\hline 5 & $1.43 \mathrm{a}$ & $\begin{array}{c}1.25 \\
b c\end{array}$ & $1.22 \mathrm{bc}$ & $\begin{array}{l}1.30 \\
\mathrm{AB}\end{array}$ & $1.52 \mathrm{a}$ & $1.30 \mathrm{bc}$ & $1.18 \mathrm{de}$ & $\begin{array}{l}1.33 \\
\mathrm{AB}\end{array}$ \\
\hline Mean & $\begin{array}{c}1.43 \\
\mathrm{~A} \\
\end{array}$ & $\begin{array}{c}1.25 \\
\mathrm{~B} \\
\end{array}$ & $1.22 \mathrm{~B}$ & & $\begin{array}{c}1.52 \\
\mathrm{~A}\end{array}$ & $1.29 \mathrm{~B}$ & $1.18 \mathrm{C}$ & \\
\hline
\end{tabular}


Cont. Table (2):

\begin{tabular}{|c|c|c|c|c|c|c|c|c|}
\hline \multicolumn{7}{|c|}{ Carotenoids (mg/g-1 f.wt) } \\
\hline 0 & $0.53 \mathrm{ab}$ & $\begin{array}{c}0.46 \\
\mathrm{bc}\end{array}$ & $0.39 \mathrm{c}$ & $0.46 \mathrm{~A}$ & $\begin{array}{c}0.69 \\
\mathrm{ab}\end{array}$ & $0.61 \mathrm{c}$ & $0.50 \mathrm{~d}$ & $0.60 \mathrm{~A}$ \\
\hline 2.5 & $0.56 \mathrm{a}$ & $\begin{array}{c}0.50 \\
\mathrm{ab}\end{array}$ & $0.41 \mathrm{c}$ & $0.49 \mathrm{~A}$ & $0.73 \mathrm{a}$ & $\begin{array}{c}0.64 \\
\mathrm{bc}\end{array}$ & $0.53 \mathrm{~d}$ & $0.63 \mathrm{~A}$ \\
\hline 5 & $0.55 \mathrm{ab}$ & $\begin{array}{c}0.48 \\
\mathrm{abc}\end{array}$ & $0.40 \mathrm{c}$ & $0.48 \mathrm{~A}$ & $0.71 \mathrm{a}$ & $\begin{array}{c}0.62 \\
\mathrm{bc}\end{array}$ & $0.51 \mathrm{~d}$ & $0.61 \mathrm{~A}$ \\
\hline Mean & $0.55 \mathrm{~A}$ & $0.48 \mathrm{~B}$ & $0.40 \mathrm{C}$ & & $0.71 \mathrm{~A}$ & $0.63 \mathrm{~B}$ & $0.51 \mathrm{C}$ & \\
\hline
\end{tabular}

In each variable, data followed by the same letters (small letters for interactions and capital letters for means) are not significantly different using Duncan multiple range test at $5 \%$ level.

Leaf $\mathrm{Na}, \mathrm{K}$ concentration and $\mathrm{Na} / \mathrm{K}$ ratio: Data presented in Table 3 show that $\mathrm{NaCl}$ stress leading to a significant $(P \leq 0.05)$ increase in the concentration of $\mathrm{Na}$ in leaves Compared to control plants in both seasons. This accumulation was pronounced and significant $(P \leq 0.05)$ between all investigated levels of salinity in the second season. On contrary, there was a significant $(P \leq 0.05)$ decrease in the uptake of $\mathrm{K}$ in parallel with increasing the level of salinity in both seasons. These responses were directly reflected on $\mathrm{Na} / \mathrm{K}$ ratio which was increased in the salt stressed plants compared to the unstressed plants in both seasons. It is well documented that $\mathrm{Na}$ is the main toxic ion which can interfere with uptake of $\mathrm{K}$ and the other nutrients in maize plants (Fortmeier and Schubert, 1995; Sumer, 2004; Eker et al., 2006). These responses could be attributed to the competition between the two elements under salt stress (Azevedo Neto and Tabosa, 2000; Shahzad et al., 2012). 
Journal of Environmental Sciences (JES)

Institute of Environmental Studies and Research, Ain Shams University

Dekhil, Maha et al.

As for the effect of foliar applications, it can be observed that Se-treated plants demonstrated a decrease in $\mathrm{Na}$ and increase in $\mathrm{K}$ relative to the untreated control in both seasons. In comparison to the untreated control, these findings reached the level of significance particularly by the treatment of Se at $2.5 \mu \mathrm{M}$ in respect to $\mathrm{K}$ in the first season and $\mathrm{Na}$ in the second one respectively. A similar trend to $\mathrm{Na}$ was observed in regard to $\mathrm{Na} / \mathrm{K}$ ratio in both seasons. These results could be explained by, that plants treated by $\mathrm{Se}$ specifically at the optimum concentration increase the activities of tonoplast $\mathrm{H}^{+}$ATPase and $\mathrm{Na}^{+} / \mathrm{H}^{+}$anti-port in the roots leading to prevent of $\mathrm{Na}$ to reach the upper tissue (Zhang et al., 2006). On the other hand, increasing of $\mathrm{K}$ and decreasing of $\mathrm{Na} / \mathrm{K}$ ratio in Se-treated plants under saline conditions could help in readjustment of osmotic balance and protect the essential processes (Gupta and Gupta, 2017).

Respecting the effect of interaction, it is obvious that generally, the treatment of Se at $2.5 \mu \mathrm{M}$ achieved the lowest decreases in $\mathrm{Na}$ concentration and $\mathrm{Na} / \mathrm{K}$ ratio; whereas, an opposite trend was observed in respect to $\mathrm{K}$ compared to the plants did not receive foliar treatment under all investigated levels of salinity in both seasons. 
Dekhil, Maha et al.

Table (3): Effect of foliar application of $\mathrm{Na}_{2} \mathrm{SeO}_{4}$ at 0 (distilled water) as a control, 2.5 and $5 \mu \mathrm{M}$ on the concentrations of $\mathrm{Na}, \mathrm{K}$ and $\mathrm{Na} / \mathrm{K}$ ratio in the leaves of maize plant irrigated with three different concentrations of saline water as $\mathrm{NaCl}$ at 90 days after sowing

\begin{tabular}{|c|c|c|c|c|c|c|c|c|}
\hline \multirow{3}{*}{$\begin{array}{c}\mathrm{Na} 2 \mathrm{So} 4 \\
(\mu \mathrm{M})\end{array}$} & \multicolumn{3}{|c|}{ Salinity levels as $\mathrm{NaCl}$} & \multirow{3}{*}{ Mean } & \multicolumn{3}{|c|}{ Salinity levels as $\mathrm{NaCl}$} & \multirow{3}{*}{ Mean } \\
\hline & $0 \mathrm{mM}$ & $\begin{array}{c}50 \\
\mathrm{mM}\end{array}$ & $\begin{array}{l}100 \\
\mathrm{mM}\end{array}$ & & $0 \mathrm{mM}$ & $\begin{array}{c}50 \\
\mathrm{mM}\end{array}$ & $100 \mathrm{mM}$ & \\
\hline & \multicolumn{3}{|c|}{2017} & & \multicolumn{3}{|c|}{2018} & \\
\hline \multicolumn{9}{|c|}{$\mathrm{Na} \%$} \\
\hline 0 & $0.81 \mathrm{bcd}$ & $1.03 \mathrm{a}$ & $1.08 \mathrm{a}$ & $0.97 \mathrm{~A}$ & $\begin{array}{c}0.92 \\
\text { de }\end{array}$ & $1.02 \mathrm{c}$ & $1.22 \mathrm{a}$ & $1.05 \mathrm{~A}$ \\
\hline 2.5 & $0.75 \mathrm{~d}$ & $\begin{array}{c}0.98 \\
a b c\end{array}$ & $1.01 \mathrm{ab}$ & $0.91 \mathrm{~A}$ & $0.87 \mathrm{e}$ & $\begin{array}{c}0.93 \\
\text { de }\end{array}$ & $1.12 \mathrm{~b}$ & $0.97 \mathrm{~B}$ \\
\hline 5 & $0.79 \mathrm{~cd}$ & $\begin{array}{c}1.00 \\
\mathrm{ab}\end{array}$ & $1.04 \mathrm{a}$ & $0.94 \mathrm{~A}$ & $0.89 \mathrm{e}$ & $\begin{array}{c}0.98 \\
\mathrm{~cd}\end{array}$ & $1.15 \mathrm{~b}$ & $1.01 \mathrm{~B}$ \\
\hline Mean & $0.78 \mathrm{~B}$ & $1.00 \mathrm{~A}$ & $1.04 \mathrm{~A}$ & & $\begin{array}{c}0.89 \\
\mathrm{C}\end{array}$ & $0.98 \mathrm{~B}$ & $1.16 \mathrm{~A}$ & \\
\hline \multicolumn{9}{|c|}{$\mathrm{K} \%$} \\
\hline 0 & $1.09 \mathrm{bc}$ & $\begin{array}{c}0.97 \\
\text { de }\end{array}$ & $0.81 \mathrm{f}$ & $0.96 \mathrm{~B}$ & $\begin{array}{c}1.13 \\
\mathrm{ab}\end{array}$ & $1.04 \mathrm{~b}$ & $0.82 \mathrm{c}$ & $1.00 \mathrm{~A}$ \\
\hline 2.5 & $1.20 \mathrm{a}$ & $\begin{array}{c}1.05 \\
\mathrm{~cd}\end{array}$ & 0.89 ef & $1.04 \mathrm{~A}$ & $1.22 \mathrm{a}$ & $\begin{array}{c}1.12 \\
\mathrm{ab}\end{array}$ & $0.89 \mathrm{c}$ & $1.08 \mathrm{~A}$ \\
\hline 5 & $1.15 \mathrm{ab}$ & $\begin{array}{c}1.00 \\
\mathrm{~cd}\end{array}$ & $0.84 \mathrm{f}$ & $\begin{array}{l}1.00 \\
\mathrm{AB}\end{array}$ & $\begin{array}{c}1.17 \\
\mathrm{ab}\end{array}$ & $\begin{array}{c}1.08 \\
\mathrm{ab}\end{array}$ & $0.88 \mathrm{c}$ & $1.04 \mathrm{~A}$ \\
\hline Mean & $1.15 \mathrm{~A}$ & $1.00 \mathrm{~B}$ & $0.85 \mathrm{C}$ & & $\begin{array}{c}1.18 \\
\text { A }\end{array}$ & $1.08 \mathrm{~B}$ & $0.86 \mathrm{C}$ & \\
\hline \multicolumn{9}{|c|}{$\mathrm{Na} / \mathrm{K}$ ratio } \\
\hline 0 & $0.74 \mathrm{~cd}$ & $\begin{array}{c}1.06 \\
\mathrm{ab}\end{array}$ & $1.35 \mathrm{a}$ & $1.05 \mathrm{~A}$ & $\begin{array}{c}0.81 \\
\text { def }\end{array}$ & $0.98 \mathrm{c}$ & $1.51 \mathrm{a}$ & $1.10 \mathrm{~A}$ \\
\hline 2.5 & $0.63 \mathrm{~d}$ & $\begin{array}{c}1.06 \\
b c\end{array}$ & $1.14 \mathrm{ab}$ & $0.94 \mathrm{~A}$ & $0.72 \mathrm{f}$ & $\begin{array}{l}0.89 \\
\text { cde }\end{array}$ & $1.26 \mathrm{~b}$ & $0.96 \mathrm{~B}$ \\
\hline 5 & $0.69 \mathrm{~d}$ & $\begin{array}{c}1.00 \\
b c\end{array}$ & $1.24 \mathrm{ab}$ & $0.98 \mathrm{~A}$ & $\begin{array}{c}0.76 \\
\text { ef }\end{array}$ & $\begin{array}{c}0.92 \\
\mathrm{~cd}\end{array}$ & $1.31 \mathrm{~b}$ & $0.99 \mathrm{~B}$ \\
\hline Mean & $0.69 \mathrm{C}$ & $1.04 \mathrm{~B}$ & $1.24 \mathrm{~A}$ & & $\begin{array}{c}0.76 \\
\mathrm{C}\end{array}$ & $0.93 \mathrm{~B}$ & $1.36 \mathrm{~A}$ & \\
\hline
\end{tabular}


Journal of Environmental Sciences (JES)

Institute of Environmental Studies and Research, Ain Shams University

Dekhil, Maha et al.

Yield and its components: Data presented in Table 4 show that generally, increasing the level of salinity resulted in significant $(P \leq 0.05)$ decreases in ear weight (g.plant $\left.{ }^{-1}\right)$, weight of kernels $\left(\right.$ g.ear $\left.^{-1}\right)$ and weight of 100 kernels (g). Several previous studies reported that salt stress especially during the reproductive phase causes reduction in the total yield of maize plants by affecting the number or weight of grains (Kaya et al., 2013). These influences could be related to the reduction that occur in photosynthesis and assimilate translocation from sources (leaves) to sinks (grains) leading to abortion or poor grain setting and filling (Lohaus et al., 2000; Schubert, 2011).

Respecting the effect of Se, it can be observed that all yield studied traits were enhanced by both investigated concentrations of of Se at 2.5 or $5 \mu \mathrm{M}$ compared to the untreated plants. Generally, the highest significant findings were obtained by the treatment of Se at $2.5 \mu \mathrm{M}$ in both seasons. Improving the quantity and quality of yield by Se as exogenous application either under normal or adverse conditions had been proved in many plant species including canola (Zahedi et al., 2009) potato (Ibrahim and Ibrahim, 2016), wheat (Shahzadi et al., 2017) and faba bean (Desoky et al., 2017). In this study, the positive effect of Se on plant growth (Table 1), photosynthetic pigments (Table 2) and $\mathrm{Na} / \mathrm{K}$ homeostasis (Table 3 ) could be reflected on the final yield of grains and its filling in the salt-stressed maize plants compared to the unstressed ones in both seasons.

Concerning the effect of interaction, it can be noticed that the treatment of Se at $2.5 \mu \mathrm{M}$ gave the highest significant increases in the yield of maize 
plants under different levels of salinity. These results reflected the crucial role of Se in different vital processes in maize plants under normal or stressful conditions.

Table (4): Effect of foliar application of $\mathrm{Na}_{2} \mathrm{SeO}_{4}$ at 0 (distilled water) as a control, 2.5 and $5 \mu \mathrm{M}$ on the yield/plant and its components of maize plants irrigated with three different concentrations of saline water as $\mathrm{NaCl}$ at 90 days after sowing.

\begin{tabular}{|c|c|c|c|c|c|c|c|c|}
\hline & \multicolumn{3}{|c|}{ Salinity levels as $\mathrm{NaCl}$} & \multirow{3}{*}{ Mean } & \multicolumn{3}{|c|}{ Salinity levels as $\mathrm{NaCl}$} & \multirow{3}{*}{ Mean } \\
\hline \multirow{2}{*}{$\begin{array}{l}\text { Na2So } \\
4(\mu \mathrm{M})\end{array}$} & $0 \mathrm{mM}$ & $\begin{array}{c}50 \\
\mathrm{mM} \\
\end{array}$ & $\begin{array}{l}100 \\
\mathrm{mM} \\
\end{array}$ & & $0 \mathrm{mM}$ & $\begin{array}{c}50 \\
\mathrm{mM} \\
\end{array}$ & $\begin{array}{l}100 \\
\mathrm{mM}\end{array}$ & \\
\hline & \multicolumn{3}{|c|}{2017} & & \multicolumn{3}{|c|}{2018} & \\
\hline \multicolumn{9}{|c|}{ Ear weight (g. plant ${ }^{-1}$ ) } \\
\hline 0 & $\begin{array}{c}405.17 \\
\text { b }\end{array}$ & $370.67 \mathrm{~d}$ & $\begin{array}{c}335.67 \\
\mathrm{f}\end{array}$ & $\begin{array}{c}370.50 \\
\text { C }\end{array}$ & $\begin{array}{c}413.17 \\
\mathrm{a}\end{array}$ & $\begin{array}{c}369.17 \\
\mathrm{~d}\end{array}$ & $\begin{array}{c}328.17 \\
f\end{array}$ & $\begin{array}{l}370 . \\
17 \mathrm{C}\end{array}$ \\
\hline 2.5 & $\begin{array}{c}424.33 \\
\mathrm{a}\end{array}$ & $390.67 \mathrm{c}$ & $\begin{array}{c}355.00 \\
\mathrm{e}\end{array}$ & $\begin{array}{c}390.00 \\
\text { A }\end{array}$ & $\begin{array}{c}431.38 \\
\mathrm{a}\end{array}$ & $\begin{array}{c}381.17 \\
\mathrm{c}\end{array}$ & $\begin{array}{c}342.17 \\
\mathrm{e}\end{array}$ & $\begin{array}{r}384 . \\
91 \mathrm{~A} \\
\end{array}$ \\
\hline 5 & $\begin{array}{c}415.45 \\
a b\end{array}$ & $\begin{array}{c}380.21 \\
\mathrm{~cd}\end{array}$ & $\begin{array}{c}345.33 \\
\text { ef }\end{array}$ & $\begin{array}{c}380.33 \\
\text { B }\end{array}$ & $\begin{array}{c}425.00 \\
\mathrm{a}\end{array}$ & $\begin{array}{c}376.50 \\
\mathrm{~cd}\end{array}$ & $\begin{array}{c}334.50 \\
\text { ef }\end{array}$ & $\begin{array}{l}378 . \\
67 \mathrm{~B}\end{array}$ \\
\hline Mean & $\begin{array}{c}414.98 \\
\text { A }\end{array}$ & $380.51 \mathrm{~B}$ & $\begin{array}{c}345.33 \\
\mathrm{C}\end{array}$ & & $\begin{array}{c}423.18 \\
\text { A }\end{array}$ & $\begin{array}{c}375.61 \\
\text { B }\end{array}$ & $\begin{array}{c}334.94 \\
\text { C }\end{array}$ & \\
\hline \multicolumn{9}{|c|}{ Weight of kernels (g.Ear-1) } \\
\hline 0 & $\begin{array}{c}174.99 \\
b c\end{array}$ & $162.20 \mathrm{~d}$ & $\begin{array}{c}136.15 \\
\mathrm{f}\end{array}$ & $\begin{array}{c}157.78 \\
\text { B }\end{array}$ & $\begin{array}{c}186.82 \\
\text { bc }\end{array}$ & $\begin{array}{c}177.60 \\
\mathrm{~d}\end{array}$ & $\begin{array}{c}149.81 \\
\mathrm{e}\end{array}$ & $\begin{array}{l}171 . \\
41 \mathrm{C}\end{array}$ \\
\hline 2.5 & $\begin{array}{c}183.18 \\
\mathrm{a}\end{array}$ & $\begin{array}{c}170.33 \\
\mathrm{~cd}\end{array}$ & $\begin{array}{c}144.44 \\
\mathrm{e}\end{array}$ & $\begin{array}{c}165.98 \\
\text { A }\end{array}$ & $\begin{array}{c}197.10 \\
\mathrm{a}\end{array}$ & $\begin{array}{c}186.15 \\
\text { bc }\end{array}$ & $\begin{array}{c}157.08 \\
\mathrm{e}\end{array}$ & $\begin{array}{l}180 . \\
11 \mathrm{~A}\end{array}$ \\
\hline 5 & $\begin{array}{c}179.72 \\
a b\end{array}$ & $165.41 \mathrm{~d}$ & $\begin{array}{c}140.42 \\
\text { ef }\end{array}$ & $\begin{array}{c}161.85 \\
\mathrm{AB}\end{array}$ & $\begin{array}{c}191.75 \\
\mathrm{ab}\end{array}$ & $\begin{array}{c}181.59 \\
\text { cd }\end{array}$ & $\begin{array}{c}153.42 \\
\mathrm{e}\end{array}$ & $\begin{array}{c}175 . \\
59 \\
\mathrm{AB}\end{array}$ \\
\hline Mean & $\begin{array}{c}179.30 \\
\text { A }\end{array}$ & $165.98 \mathrm{~B}$ & $\begin{array}{c}140.34 \\
C\end{array}$ & & $\begin{array}{c}191.89 \\
\text { A }\end{array}$ & $\begin{array}{c}181.78 \\
\text { B }\end{array}$ & $\begin{array}{c}153.44 \\
\mathrm{C}\end{array}$ & \\
\hline
\end{tabular}


Cont. Table (4):

\begin{tabular}{|c|c|c|c|c|c|c|c|c|}
\hline \hline \multicolumn{10}{|c|}{ Weight of 100-kernals (g) } \\
\hline \multirow{2}{*}{0} & $\begin{array}{c}42.30 \\
\mathrm{ab}\end{array}$ & $\begin{array}{c}36.92 \\
\mathrm{bcd}\end{array}$ & $\begin{array}{c}30.49 \\
\mathrm{~d}\end{array}$ & $\begin{array}{c}36.57 \\
\mathrm{~A}\end{array}$ & $\begin{array}{c}49.32 \\
\mathrm{abc}\end{array}$ & $\begin{array}{c}43.44 \\
\mathrm{bcd}\end{array}$ & $\begin{array}{c}39.23 \\
\mathrm{~d}\end{array}$ & $\begin{array}{c}44.0 \\
0 \mathrm{~A}\end{array}$ \\
\hline \multirow{2}{*}{2.5} & $\begin{array}{c}46.35 \\
\mathrm{a}\end{array}$ & $\begin{array}{c}39.06 \\
\mathrm{abc}\end{array}$ & $\begin{array}{c}32.43 \\
\mathrm{~cd}\end{array}$ & $\begin{array}{c}39.28 \\
\mathrm{~A}\end{array}$ & $53.53 \mathrm{a}$ & $\begin{array}{c}47.07 \\
\mathrm{abcd}\end{array}$ & $\begin{array}{c}42.65 \\
\mathrm{bcd}\end{array}$ & $\begin{array}{c}47.7 \\
5 \mathrm{~A}\end{array}$ \\
\hline \multirow{2}{*}{5} & $\begin{array}{c}43.06 \\
\mathrm{ab}\end{array}$ & $\begin{array}{c}37.12 \\
\mathrm{bcd}\end{array}$ & $\begin{array}{c}31.87 \\
\mathrm{~cd}\end{array}$ & $\begin{array}{c}37.35 \\
\mathrm{~A}\end{array}$ & $\begin{array}{c}51.37 \\
\mathrm{ab}\end{array}$ & $\begin{array}{c}45.61 \\
\mathrm{abcd}\end{array}$ & $\begin{array}{c}40.43 \\
\mathrm{~cd}\end{array}$ & $\begin{array}{c}45.8 \\
0 \mathrm{~A}\end{array}$ \\
\hline \multirow{2}{*}{ Mean } & $\begin{array}{c}43.90 \\
\mathrm{~A}\end{array}$ & $37.70 \mathrm{~B}$ & $\begin{array}{c}31.60 \\
\mathrm{C}\end{array}$ & & $\begin{array}{c}51.40 \\
\mathrm{~A}\end{array}$ & $\begin{array}{c}45.37 \\
\mathrm{~B}\end{array}$ & $\begin{array}{c}40.77 \\
\mathrm{~B}\end{array}$ & \\
\hline
\end{tabular}

In each variable, data followed by the same letters (small letters for interactions and capital letters for means) are not significantly different using Duncan multiple range test at $5 \%$ level.

\section{CONCLUSION}

The present study indicated that application of Se at low concentration $(2.5 \mu \mathrm{M})$ enhanced growth, leaf pigments, the balance between $\mathrm{Na}$ and $\mathrm{K}$ and eventually the yield and its components of maize plants under salt stress conditions. Selenium as foliar applications could be recommended in order to mitigate the adverse effects of salt stress on maize plants.

\section{REFERENCES}

Allu, A. D.; A. M. Soja; A. Wu; J. Szymanski and S. Balazadeh. (2014). Salt stress and senescence: identification of cross-talk regulatory components. Journal of Experimental Botany, 65 (14): 39934008 .

Amweg, E.; D. Stuart and D. Weston. (2003). Comparative bioavailability of selenium to aquatic organisms after biological treatment of agricultural drainage water. Aquatic Toxicology, 63 (1): 13-25. 
Azevedo Neto, A. D. d. and J. N. Tabosa. (2000). Salt stress in maize seedlings: part II distribution of cationic macronutrients and its relation with sodium. Revista Brasileira de Engenharia Agrícola e Ambiental, 4 (2): 165-171.

Barakat, H. (2003). Interactive effects of salinity and certain vitamins on gene expression and cell division. Int J Agric Biol, 3: 219-225.

Cartes, P.; A. Jara; L. Pinilla; A. Rosas and M. Mora. (2010). Selenium improves the antioxidant ability against aluminium-induced oxidative stress in ryegrass roots. Annals of Applied Biology, 156 (2): 297-307.

Chu, J.; X. Yao and Z. Zhang. (2010). Responses of wheat seedlings to exogenous selenium supply under cold stress. Biological trace element research, 136 (3): 355-363.

Costache, M. A.; G. Campeanu and G. Neata. (2012). Studies concerning the extraction of chlorophyll and total carotenoids from vegetables. Romanian Biotechnological Letters, 17 (5): 7702-7708.

Cottenie, A.; M. Verloo; L. Kiekens; G. Velghe and R. Camerlynck. (1982). Chemical analysis of plants and soils. IWONL, Brussels, 63

Cramer, G.; G. Alberico and C. Schmidt. (1994). Leaf expansion limits dry matter accumulation of salt-stressed maize. Functional Plant Biology, 21 (5): 663-674.

Dash, M. and S. Panda. (2001). Salt stress induced changes in growth and enzyme activities in germinating Phaseolus mungo seeds. Biologia plantarum, 44 (4): 587-589.

Desoky, E.; D. Abdelaziz and M. Boghdady. (2017). Effect of Selenium on Growth, Physiological Aspects and Productivity of Faba Bean (Vicia faba L.).

Dhugga, K. S. (2007). Maize biomass yield and composition for biofuels. Crop Science, 47 (6): 2211-2227. 
Diao, M.; L. Ma; J. Wang; J. Cui; A. Fu and H.-y. Liu. (2014). Selenium promotes the growth and photosynthesis of tomato seedlings under salt stress by enhancing chloroplast antioxidant defense system. Journal of plant growth regulation, 33 (3): 671-682.

Djanaguiraman, M.; P. V. Prasad and M. Seppanen. (2010). Selenium protects sorghum leaves from oxidative damage under high temperature stress by enhancing antioxidant defense system. Plant physiology and biochemistry, 48 (12): 999-1007.

Eker, S.; G. Cömertpay; Ö. Konuşkan; A. C. Ülger; L. Öztürk and İ. Çakmak. (2006). Effect of salinity stress on dry matter production and ion accumulation in hybrid maize varieties. Turkish journal of agriculture and forestry, 30 (5): 365-373.

Elkelish, A. A.; M. H. Soliman; H. A. Alhaithloul and M. A. El-Esawi. (2019). Selenium protects wheat seedlings against salt stressmediated oxidative damage by up-regulating antioxidants and osmolytes metabolism. Plant physiology and biochemistry, 137: 144-153.

Fahad, S.; S. Hussain; A. Matloob; F. A. Khan; A. Khaliq; S. Saud; S. Hassan; D. Shan; F. Khan and N. Ullah. (2015). Phytohormones and plant responses to salinity stress: a review. Plant growth regulation, 75 (2): 391-404.

Farooq, M.; M. Hussain; A. Wakeel and K. H. Siddique. (2015). Salt stress in maize: effects, resistance mechanisms, and management. A review. Agronomy for Sustainable Development, 35 (2): 461-481.

Fortmeier, R. and S. Schubert. (1995). Salt tolerance of maize (Zea mays L.): the role of sodium exclusion. Plant, cell \& environment, 18 (9): 1041-1047.

Germ, M.; I. Kreft; V. Stibilj and O. Urbanc-Berčič. (2007). Combined effects of selenium and drought on photosynthesis and mitochondrial respiration in potato. Plant physiology and biochemistry, 45 (2): 162-167. 
Gupta, M. and S. Gupta. (2017). An overview of selenium uptake, metabolism, and toxicity in plants. Frontiers in Plant Science, 7: 2074.

Habibi, G. (2017). Selenium ameliorates salinity stress in Petroselinum crispum by modulation of photosynthesis and by reducing shoot $\mathrm{Na}$ accumulation. Russian journal of plant physiology, 64 (3): 368-374.

Hartikainen, H.; T. Xue and V. Piironen. (2000). Selenium as an anti-oxidant and pro-oxidant in ryegrass. Plant and Soil, 225 (1-2): 193-200.

Hasanuzzaman, M.; M. A. Hossain and M. Fujita. (2010). Selenium in higher plants: physiological role, antioxidant metabolism and abiotic stress tolerance. J Plant Sci, 5 (4): 354-375.

Hashem, H. A.; R. A. Hassanein; M. A. Bekheta and F. A. El-Kady. (2013). Protective role of selenium in canola (Brassica napus L.) plant subjected to salt stress. Egypt J Exp Biol (Bot), 9 (2): 199-211.

Hawrylak-Nowak, B. (2009). Beneficial effects of exogenous selenium in cucumber seedlings subjected to salt stress. Biological trace element research, 132 (1-3): 259-269.

Hniličková, H.; F. Hnilička; J. Martinkova and K. Kraus. (2017). Effects of salt stress on water status, photosynthesis and chlorophyll fluorescence of rocket. Plant, Soil and Environment, 63 (8): 362367.

Ibrahim, M. and H. A. Ibrahim. (2016). Assessment of Selenium Role in Promoting or Inhibiting Potato Plants under Water Stress. Journal of Horticultural Science \& Ornamental Plants, 8 (3): 125-139.

Jamil, M.; M. Ashraf; S. Rehman; M. Ahmad and E. S. Rha. (2012). Salinity induced changes in cell membrane stability, protein and RNA contents. African Journal of Biotechnology, 11 (24): 6476-6483. 
Jiang, C.; C. Zu; D. Lu; Q. Zheng; J. Shen; H. Wang and D. Li. (2017). Effect of exogenous selenium supply on photosynthesis, $\mathrm{Na}+$ accumulation and antioxidative capacity of maize (Zea mays L.) under salinity stress. Scientific reports, 7: 42039.

Katerji, N.; J. Van Hoorn; A. Hamdy; F. Karam and M. Mastrorilli. (1996). Effect of salinity on water stress, growth, and yield of maize and sunflower. Agricultural Water Management, 30 (3): 237-249.

Kaya, C.; M. Ashraf; M. Dikilitas and A. L. Tuna. (2013). Alleviation of salt stress-induced adverse effects on maize plants by exogenous application of indoleacetic acid (IAA) and inorganic nutrients-A field trial. Australian Journal of Crop Science, 7 (2): 249.

Khalifa, G.; M. Abdelrassoul; A. Hegazi and M. Elsherif. (2016). Mitigation of saline stress adverse effects in lettuce plant using selenium and silicon. Middle East J Agric Res, 5 (3): 347-361.

Kleinmans, J.; R. Densley; T. Hurley and I. Williams. (2016). BRIEF COMMUNICATION: Feed value of maize silage in New Zealand-a review. In Proceedings of the New Zealand Society of Animal Production, Vol 76, pp 100-102.

Lohaus, G.; M. Hussmann; K. Pennewiss; H. Schneider; J. J. Zhu and B. Sattelmacher. (2000). Solute balance of a maize (Zea mays L.) source leaf as affected by salt treatment with special emphasis on phloem retranslocation and ion leaching. Journal of Experimental Botany, 51 (351): 1721-1732.

Menezes-Benavente, L.; S. P. Kernodle; M. Margis-Pinheiro and J. G. Scandalios. (2004). Salt-induced antioxidant metabolism defenses in maize (Zea mays L.) seedlings. Redox report, 9 (1): 29-36.

Moldovan, C.; I. Ianculov; N. G. Hădărugă; D. Dumbravă; E. Crăiniceanu; M. Drugă; L. Alda and G. Moldovan. (2009). Influence of chlorophyll content from onion (Allium cepa) after selenium and zinc adding. Journal of Agroalimentary Processes and Technologies, 15 (3): 437-440. 
Munns, R. (2002). Comparative physiology of salt and water stress. Plant, cell \& environment, 25 (2): 239-250.

Munns, R. (2005). Genes and salt tolerance: bringing them together. New Phytologist, 167 (3): 645-663.

Munns, R. and M. Tester. (2008). Mechanisms of salinity tolerance. Annu. Rev. Plant Biol., 59: 651-681.

Ostrander, B. M. (2015). Maize Starch for Industrial Applications. In Cruz, V. M. V. and D. A. Dierig, eds, Industrial Crops: Breeding for BioEnergy and Bioproducts. Springer New York, New York, NY, pp 171-189.

Pang, C.-H. and B.-S. Wang. (2008). Oxidative Stress and Salt Tolerance in Plants. In Lüttge, U.; W. Beyschlag and J. Murata, eds, Progress in Botany. Springer Berlin Heidelberg, Berlin, Heidelberg, pp 231-245.

Parida, A.; A. Das and B. Mittra. (2003). Effects of $\mathrm{NaCl}$ stress on the structure, pigment complex composition, and photosynthetic activity of mangrove Bruguiera parviflora chloroplasts. Photosynthetica, 41 (2): 191.

Parvaiz, M. (2014). Response of Maize to salt stress a critical review. International Journal of Healthcare Sciences (IJHS), 1 (1): 13-25.

Sabbagh, E.; M. Lakzayi; A. Keshtehgar and K. Rigi. (2014). The effect of salt stress on respiration, PSII function, chlorophyll, carbohydrate and nitrogen content in crop plants. Intl J Farm \& Alli Sci, 3 (9): 988-993.

Sade, N.; M. del Mar Rubio-Wilhelmi; K. Umnajkitikorn and E. Blumwald. (2017). Stress-induced senescence and plant tolerance to abiotic stress. Journal of Experimental Botany, 69 (4): 845-853.

Saffaryazdi, A.; M. Lahouti; A. Ganjeali and H. Bayat. (2012). Impact of selenium supplementation on growth and selenium accumulation on spinach (Spinacia oleracea L.) plants. Notulae Scientia Biologicae, 4 (4): 95-100. 
SAS. (1988). SAS/STAT User's Guide: Release 6.03 ed. . SAS Inst. Inc., Cary,NC.,

Schleiff, U. (2008). Analysis of water supply of plants under saline soil conditions and conclusions for research on crop salt tolerance. Journal of Agronomy and Crop Science, 194 (1): 1-8.

Schubert, S. (2011). Salt resistance of crop plants: physiological characterization of a multigenic trait. The molecular and physiological basis of nutrient use efficiency in crops, 13: 443455.

Seckin, B.; A. H. Sekmen and I. Türkan. (2009). An enhancing effect of exogenous mannitol on the antioxidant enzyme activities in roots of wheat under salt stress. Journal of plant growth regulation, 28 (1): 12 .

Shahzad, M.; K. Witzel; C. Zörb and K. Mühling. (2012). Growth-related changes in subcellular ion patterns in maize leaves (Zea mays L.) under salt stress. Journal of Agronomy and Crop Science, 198 (1): 46-56.

Shahzadi, I.; M. Iqbal; R. Rasheed; M. A. Ashraf; S. Perveen and M. Hussain. (2017). Foliar application of selenium increases fertility and grain yield in bread wheat under contrasting water availability regimes. Acta Physiologiae Plantarum, 39 (8): 173.

Shi, Q.; F. Ding; X. Wang and M. Wei. (2007). Exogenous nitric oxide protect cucumber roots against oxidative stress induced by salt stress. Plant physiology and biochemistry, 45 (8): 542-550.

Soufan, W. and M. K. Okla. (2014). Effect of salt stress on germination, growth and yield of maize (Zea mays L. CV. Ghota-1). Journal of Pure and Applied Microbiology, 8 (1): 185-194.

Sumer, A. (2004). Evidence of sodium toxicity for the vegetative growth of maize during the first phase of salt stress. J. App. Bot., 78: 135139. 
Tabur, S. and K. Demir. (2010). Role of some growth regulators on cytogenetic activity of barley under salt stress. Plant growth regulation, 60 (2): 99-104.

Turakainen, M.; H. Hartikainen and M. M. Seppänen. (2004). Effects of selenium treatments on potato (Solanum tuberosum L.) growth and concentrations of soluble sugars and starch. Journal of agricultural and food chemistry, 52 (17): 5378-5382.

Valenzuela, C. E.; O. Acevedo-Acevedo; G. S. Miranda; P. Vergara-Barros; L. Holuigue; C. R. Figueroa and P. M. Figueroa. (2016). Salt stress response triggers activation of the jasmonate signaling pathway leading to inhibition of cell elongation in Arabidopsis primary root. Journal of Experimental Botany, 67 (14): 42094220.

Valkama, E.; M. Kivimäenpää; H. Hartikainen and A. Wulff. (2003). The combined effects of enhanced UV-B radiation and selenium on growth, chlorophyll fluorescence and ultrastructure in strawberry (Fragariax ananassa) and barley (Hordeum vulgare) treated in the field. Agricultural and Forest Meteorology, 120 (1-4): 267-278.

Xue, T.; H. Hartikainen and V. Piironen. (2001). Antioxidative and growthpromoting effect of selenium on senescing lettuce. Plant and Soil, 237 (1): 55-61.

Zahedi, H.; G. Noormohammadi; A. H. S. Rad; D. Habibi and M. M. A. Boojar. (2009). Effect of zeolite and foliar application of selenium on growth, yield and yield component of three canola cultivar under conditions of late season drought stress. Notulae Scientia Biologicae, 1 (1): 73-80.

Zhang, S.; J. Song; H. Wang and G. Feng. (2010). Effect of salinity on photosynthesis and chloroplasts ultrastructure in cotyledons of desiccated seeds of halophytes or xerophyte growing in central Asia. J. Plant Ecol, 3: 259-267. 
Zhang, Y.; L. Wang; Y. Liu; Q. Zhang; Q. Wei and W. Zhang. (2006). Nitric oxide enhances salt tolerance in maize seedlings through increasing activities of proton-pump and $\mathrm{Na}+\mathrm{H}+$ antiport in the tonoplast. Planta, 224 (3): 545-555.

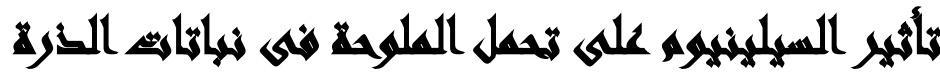

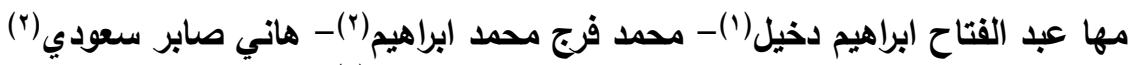

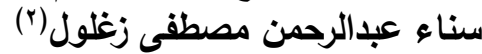

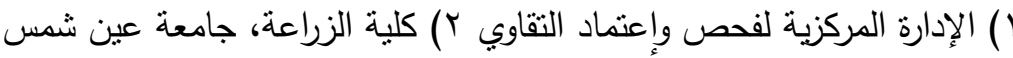

\section{المستخلئ}

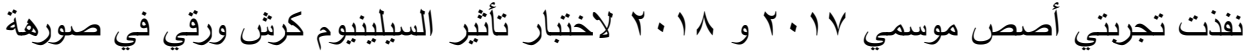

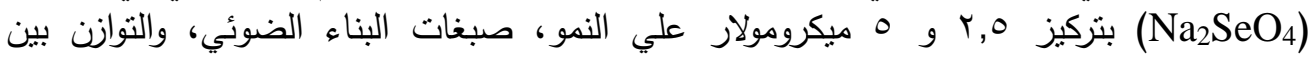

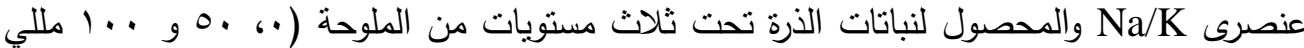

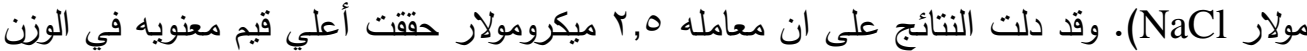

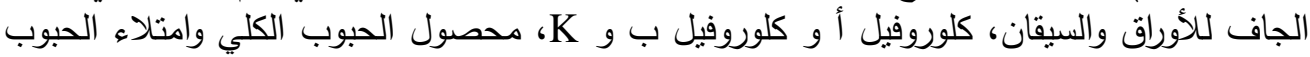

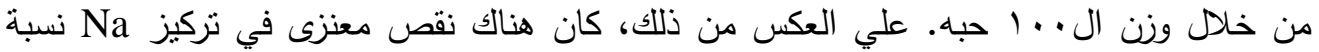
المع/Ka/K بينما لم تبدى الكاروتينات اي تغييرات معنويه بين النباتات المعاملة بالسيلينيوم وغير تركير المعاملة. الكلمات الالية: ذرة، سيلينيوم، ملوحة، الصبغات، نسبة الايونات والمحصول. 